\title{
Clinical, Diagnostic, and Treatment Disparities between HIV-Infected and Non-HIV-Infected Immunocompromised Patients with Pneumocystis jirovecii Pneumonia
}

\author{
Helmut J.F. Salzer ${ }^{a, b}$ Guido Schäfer ${ }^{c, d}$ Martin Hoenigle, $f$ \\ Gunar Günther ${ }^{a, g}$ Christian Hoffmann ${ }^{\text {h, }}$ i Barbara Kalsdorf ${ }^{a, b}$ \\ Alexandre Alanio $^{\mathrm{j}-1}$ Christoph Lange ${ }^{\mathrm{a}, \mathrm{b}, \mathrm{m}, \mathrm{n}}$

\begin{abstract}
a Division of Clinical Infectious Diseases, Research Center Borstel, Leibniz Lung Center, Borstel, Germany;
${ }^{b}$ German Center for Infection Research, Clinical Tuberculosis Center, Borstel, Germany; ' Infectious Diseases Clinic, University Medical Center Hamburg-Eppendorf, Hamburg, Germany; ${ }^{\mathrm{d} S e c t i o n}$ of Rheumatology, 3rd Department

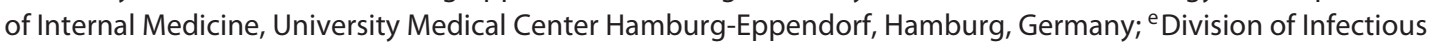
Diseases, University of California at San Diego, San Diego, CA, USA; ${ }^{f}$ Section of Infectious Diseases and Tropical Medicine and Division of Pulmonology, Medical University of Graz, Graz, Austria; ${ }^{9}$ Department of Internal Medicine,

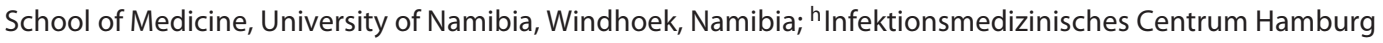
(ICH) Study Center, Hamburg, Germany; 'Department of Medicine II, University Hospital of Schleswig-Holstein,

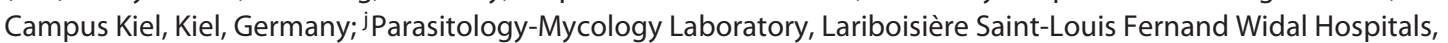
Assistance Publique-Hôpitaux de Paris, Paris, France; ${ }^{k}$ Paris-Diderot, Sorbonne Paris Cité University, Paris, France; IInstitut Pasteur, Molecular Mycology Unit, CNRS CMR2000, Paris, France; ${ }^{\mathrm{m}}$ International Health/Infectious Diseases, University of Lübeck, Lübeck, Germany; ${ }^{n}$ Department of Medicine, Karolinska Institutet, Stockholm, Sweden
\end{abstract}

\section{Keywords}

Pneumocystis jirovecii · Pneumocystis jirovecii pneumonia · Pneumonia · HIV-infected patients · Non-HIV-infected patients · Diagnosis - Treatment

\begin{abstract}
The substantial decline in the Pneumocystis jirovecii pneumonia (PCP) incidence in HIV-infected patients after the introduction of antiretroviral therapy (ART) in resource-rich settings and the growing number of non-HIV-infected immunocompromised patients at risk leads to considerable epidemiologic changes with clinical, diagnostic, and treatment consequences for physicians. HIV-infected patients usually develop a subacute course of disease, while non-HIVinfected immunocompromised patients are characterized
\end{abstract}

\section{KARGER}

(c) 2018 S. Karger AG, Basel

E-Mail karger@karger.com

www.karger.com/res by a rapid disease progression with higher risk of respiratory failure and higher mortality. The main symptoms usually include exertional dyspnea, dry cough, and subfebrile temperature or fever. Lactate dehydrogenase may be elevated. Typical findings on computed tomography scans of the chest are bilateral ground-glass opacities with or without cystic lesions, which are usually associated with the presence of AIDS. Empiric treatment should be initiated as soon as PCP is suspected. Bronchoalveolar lavage has a higher diagnostic yield compared to induced sputum. Immunofluorescence is superior to conventional staining. A combination of different diagnostic tests such as microscopy, polymerase chain reaction, and (1,3)- $\beta$-D-glucan is recommended. Trimethoprim/sulfamethoxazole for 21 days is the treatment of choice in adults and children. Alternative treatment regimens include dapsone with trimethoprim, clindamycin with 
primaquine, atovaquone, or pentamidine. Patients with moderate to severe disease should receive adjunctive corticosteroids. In newly diagnosed HIV-infected patients with PCP, ART should be initiated as soon as possible. In non-HIVinfected immunocompromised patients, improvement of the immune status should be discussed (e.g., temporary reduction of immunosuppressive agents). PCP prophylaxis is effective and depends on the immune status of the patient and the underlying immunocompromising disease.

(c) 2018 S. Karger AG, Basel

\section{Case Report}

A 48-year-old previously healthy man was admitted to our hospital with a 5-week medical history of increasing exercise-induced shortness of breath. He had lost $6 \mathrm{~kg}$ of weight within the last 2 months. During the past 3 weeks he had experienced night sweats. He reported increasing dry cough over 4 days prior to admission.

Upon admission his body mass index was $22.8(180 \mathrm{~cm}, 74 \mathrm{~kg})$. He was in a trained physical condition. Musculoskeletal system examination and neurological examination were without pathological findings. On the skin of his forehead there was an efflorescence compatible with seborrheic dermatitis. There was no jaundice, anemia, finger clubbing, or cyanosis present. On the neck, both axillas, and groins there were pea-sized palpable lymph nodes. He was febrile with a temperature of $39.5^{\circ} \mathrm{C}$. Cottage cheese-like plaques were visible on the hard palate and pharynx, compatible with Candida stomatitis and pharyngitis. His heart rate was 92 beats/min and his blood pressure 120/70 $\mathrm{mm} \mathrm{Hg}$. His respiration rate at rest was 23 breaths $/ \mathrm{min}$. The breath sounds were vesicular over both lung fields. Arterial blood gas analysis showed

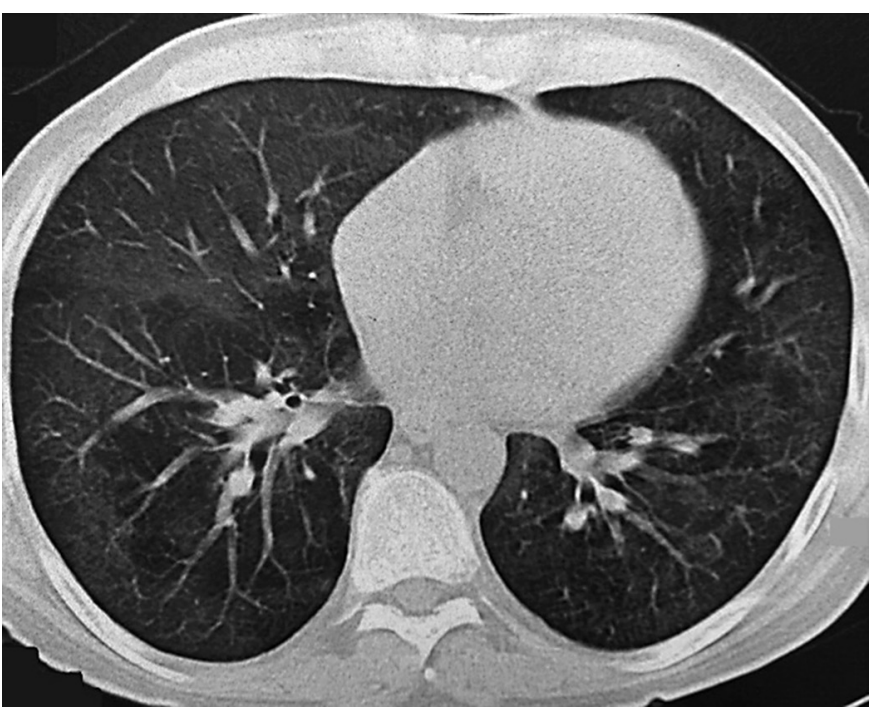

Fig. 1. Axial computed tomography scan of the chest showing diffuse bilateral ground-glass opacities due to an alveolitis in Pneumocystis jirovecii pneumonia. a pO $\mathrm{p}_{2}$ of $62 \mathrm{~mm} \mathrm{Hg}$, a pCO $\mathrm{pO}_{2}$ of $31 \mathrm{~mm} \mathrm{Hg}$, and a pH of 7.47 on room air. Oxygen saturation was $92 \%$ and dropped to $86 \%$ after 3 min of walking horizontally. Lung function test showed a reduced forced vital capacity of $64 \%$ with a nonobstructive forced expiratory volume in $1 \mathrm{~s} /$ forced vital capacity ratio of $96 \%$, indicating a restrictive spirometry pattern with a reduced diffusing capacity of the lung of $35 \%$.

Routine laboratory values were within normal limits, except for a serum lactate dehydrogenase (LDH) level of $338 \mathrm{U} / \mathrm{L}$ (normal $<252 \mathrm{U} / \mathrm{L}$ ), a hemoglobin concentration of $12.1 \mathrm{~g} / \mathrm{dL}$ (normal 13.5$17.5 \mathrm{~g} / \mathrm{dL}$ ), and a C-reactive protein level of $2.08 \mathrm{mg} / \mathrm{dL}$ (normal $<0.5 \mathrm{mg} / \mathrm{dL}$ ). An HIV screening test was reactive with a positive HIV-1 Western blot test result. The HIV RNA concentration was 34,618 copies $/ \mathrm{mL}$. The number of circulating CD4+ T lymphocytes was $124 / \mu \mathrm{L}(7 \%)$ and the number of CD8+ T lymphocytes was 1,276/ $\mu \mathrm{L}(67 \%)$, resulting in a CD4:CD8 ratio of 0.1 (normal 1.2-2.7).

Chest X-ray showed bilateral perihilar ground-glass opacities with interstitial thickening. There was no pleural effusion or cavitation visible. A computed tomography (CT) scan of the chest showed multifocal ground-glass opacities, compatible with the diagnosis of alveolitis (Fig. 1).

On bronchoscopy the visual aspect of the trachea and bronchial tree was without pathological findings. Bronchoalveolar lavage (BAL) demonstrated $16 \times 10^{6}$ cells $/ 100 \mathrm{~mL}$ (normal 3-12 $\times$ $10^{6}$ cells $/ 100 \mathrm{~mL}$ ), with a differential cell count of $13 \%$ lymphocytes (normal $<10 \%$ ), 26\% macrophages (normal $>85 \%$ ), $60 \%$ neutrophils (normal $<3 \%$ ), and $1 \%$ eosinophils (normal $<0.5 \%$ ). GrocottGomori methenamine silver staining of the BAL fluid identified multiple spherical, oval asci/cysts 5-6 $\mu \mathrm{m}$ in diameter, compatible with the diagnosis of Pneumocystis jirovecii pneumonia (PCP) (Fig. 2). Treatment with trimethoprim/sulfamethoxazole (TMP/ SMX) for 21 days as well as antiretroviral therapy (ART) was initiated. After 8 weeks the patient's symptoms and radiological changes had resolved completely.

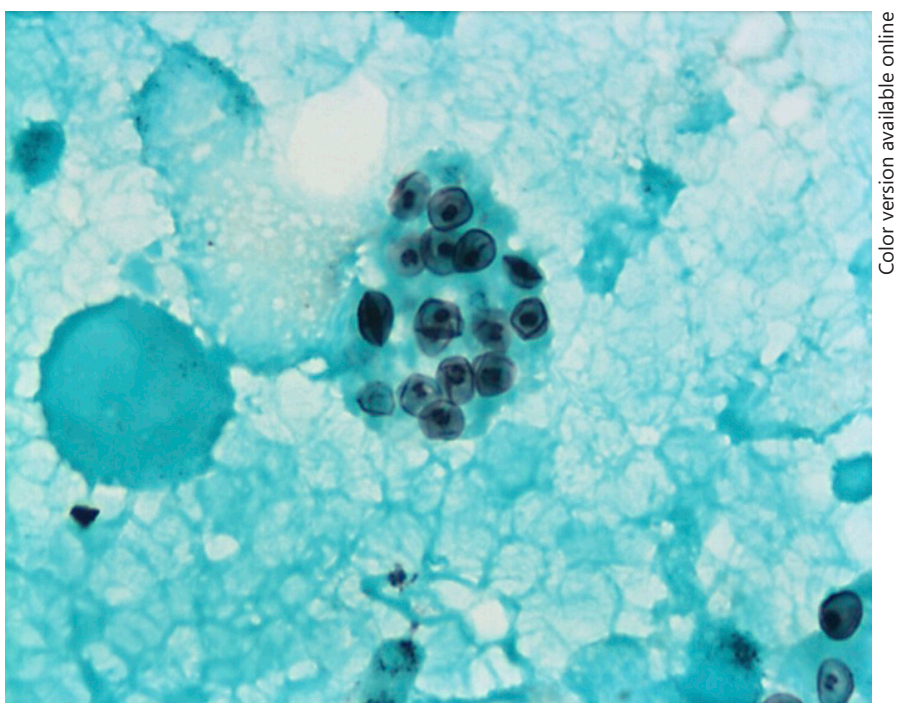

Fig. 2. Microscopic image of black Pneumocystis jirovecii cysts of 5-6 $\mu \mathrm{m}$ in a bronchoalveolar lavage fluid cell pellet after centrifugation. Grocott-Gomori methenamine silver staining, $\times 1,000$. 


\section{Epidemiology and Risk Groups}

\section{HIV-Infected Patients}

While PCP was rarely described before the HIV/AIDS epidemic, the incidence of PCP increased rapidly during the 1980s, with PCP occurring in $75 \%$ of individuals with AIDS, resulting in mortality rates up to $40 \%$ [1]. Given the fact that $>90 \%$ of PCP cases occurred in patients with CD4+ T lymphocyte counts $<200$ cells $/ \mathrm{mm}^{3}$, the infection became one of the main AIDS-defining illnesses [1]. Since then, the widespread use of PCP prophylaxis with TMP/SMX and early ART have led to a substantial decline in the PCP incidence among individuals with HIV infection. Studies in the early 2000 s reported an incidence of PCP among HIV-infected individuals below 1 case per 100 person-years [2-8]. Given the trend towards earlier diagnosis of HIV infection and immediate ART independent of CD4+ T cell count, the incidence of PCP in HIV patients has likely decreased further during recent years [9-12].

Despite its decreasing incidence, PCP is still a serious health concern for people living with HIV/AIDS [13]. Since there is no national surveillance for PCP in the United States and other resource-rich countries, the exact number of cases is difficult to determine. While fewer $\mathrm{HIV}$-infected individuals develop opportunistic infections in resource-rich settings overall, PCP is still one of the most common opportunistic infections in HIV patients in the United States, Canada, and Europe $[2,13]$. It mainly affects individuals who are unaware of their HIV infection or who get diagnosed late (i.e., late presenters) or are not receiving ongoing care for HIV infection [14, 15]. Late HIV diagnosis as the major risk factor for PCP is significantly more frequent among populations suffering from healthcare disparities [16]. PCP remains also very common as an opportunistic infection among people living with HIV/AIDS in resource-limited countries (see PCP from a Global Health Perspective with Emphasis on Resource-Limited Settings) [17].

\section{Non-HIV-Infected Patients with Other \\ Immunocompromising Reasons}

PCP is increasingly diagnosed in non-HIV-infected immunocompromised patients, indicating new challenges for the diagnosis, treatment, and prophylaxis in a larger susceptible population [18-20]. In contrast to HIVinfected patients, there is evidence for a more acute onset of symptoms, faster progression of disease, poorer outcome, higher mortality, and higher risk of coinfections [9, 21-24].

HIV-Infected and Non-HIV-Infected Immunocompromised Patients with PCP
Posttransplant Patients. Both patients undergoing hematopoietic stem cell transplantation (HSCT) and patients undergoing solid organ transplantation (SOT) are at risk of PCP (5-15\% of cases), which is higher after allogenic versus autologous HSCT and after heart and/or lung SOT versus for instance renal transplantation [19, 20, 25, 26].

Hematooncologic Patients. Particularly patients with leukemia (such as acute lymphatic leukemia) and lymphoproliferative disorders (such as chronic lymphatic leukemia and non-Hodgkin lymphomas) have a substantial risk of developing PCP. Certain chemotherapeutic agents are more predisposing to PCP, including corticosteroids, cyclophosphamide, methotrexate, vincristine, cytarabine, fludarabine, temozolomide, rituximab, alemtuzumab, ibrutinib, and idelalisib [27-30].

Patients under Immunosuppressive Drugs due to Autoimmune Diseases. Inflammatory diseases, their complications, and immunosuppressive regimens contribute to the risk of PCP. Up to $20 \%$ of PCP cases occur in patients with inflammatory diseases, the incidence being especially high in cases of polyarteritis nodosa, granulomatosis with polyangiitis, dermatomyositis/polymyositis, and interstitial lung diseases in patients with rheumatoid arthritis $[31,32]$. Furthermore, it depends on the administered immunosuppressant, with following drugs most frequently mentioned: prolonged medium- to high-dose glucocorticoids, cyclophosphamide, rituximab, alemtuzumab, and tumor necrosis factor alpha antagonists [33, 34].

\section{Clinical and Radiological Presentation of PCP}

\section{Signs and Symptoms}

The classic triad of PCP symptoms in AIDS patients includes (1) subacute onset of exertional dyspnea, (2) dry and nonproductive cough, and (3) fever or subfebrile temperatures (Table 1). The subacute course over several days and even weeks often allows differentiation from bacterial pneumonia. Oral thrush and substantial weight loss are also frequently seen in AIDS patients with PCP, as demonstrated in our patient. However, despite the subacute course, deterioration may occur rapidly.

A diagnostic hallmark is respiratory insufficiency, which should be confirmed by arterial blood gas analysis. LDH is often elevated and may have limited use as a predictive parameter for the course of disease. However, a high LDH level is an unfavorable sign and may reflect the severity of the PCP. In contrast, C-reactive protein is of- 
Table 1. Disease characteristics of PCP in HIV-positive patients compared to patients with other reasons of immunosuppression

\begin{tabular}{|c|c|c|c|}
\hline $\begin{array}{l}\text { Disease } \\
\text { characteristics }\end{array}$ & HIV-positive/AIDS patients & $\begin{array}{l}\text { HIV-negative } \\
\text { immunocompromised patients }\end{array}$ & Commentary \\
\hline Signs and symptoms & $\begin{array}{l}\text { the classic triad in AIDS patients } \\
\text { includes (1) exertional dyspnea, } \\
\text { (2) dry, nonproductive cough, and } \\
\text { (3) fever or subfebrile temperatures }\end{array}$ & $\begin{array}{l}\text { the main symptoms include fever, } \\
\text { dyspnea, and nonproductive cough; } \\
\text { hypoxia/respiratory failure are more } \\
\text { frequent; dyspnea and cough are less } \\
\text { frequent; elevation of LDH is less } \\
\text { frequent }\end{array}$ & $\begin{array}{l}\mathrm{LDH} \text { is of poor predictive } \\
\text { value }\end{array}$ \\
\hline $\begin{array}{l}\text { Severity and } \\
\text { course of disease }\end{array}$ & $\begin{array}{l}\text { subacute onset of symptoms; } \\
\text { subacute/chronic course (several } \\
\text { days to weeks); risk to suddenly } \\
\text { deteriorate after a long stable phase } \\
\text { of disease }\end{array}$ & $\begin{array}{l}\text { acute onset of clinical symptoms; } \\
\text { rapid disease progression (days) }\end{array}$ & $\begin{array}{l}\text { higher mortality in } \\
\text { HIV-negative } \\
\text { immunocompromised } \\
\text { patients }(35-50 \%)\end{array}$ \\
\hline \multirow[t]{2}{*}{ CT scan of the chest } & \multicolumn{3}{|c|}{ bilateral ground-glass opacities (perihilar, diffuse, and/or mosaic pattern) } \\
\hline & $\begin{array}{l}\text { thin-walled cystic lesions of variable } \\
\text { size and forms more associated with } \\
\text { AIDS }\end{array}$ & $\begin{array}{l}\text { typically widespread ground-glass } \\
\text { opacities; less frequently associated } \\
\text { with cystic lesions; nodules, } \\
\text { consolidations, and pleural effusions } \\
\text { may be seen more often }\end{array}$ & \\
\hline
\end{tabular}

CT, computed tomography; LDH, lactate dehydrogenase; PCP, Pneumocystis jirovecii pneumonia.

ten normal, provided there are no other concurrent infections.

Numerous studies have compared the clinical features and the outcome of HIV-infected and non-HIV-infected cases. These comparisons should be considered with caution, as the clinical and therapeutic background of PCP in non-HIV-infected patients with variable immunocompromising disorders is very diverse. In large retrospective cohort studies of PCP cases, however, non-HIVinfected patients were less symptomatic at diagnosis than AIDS patients [19]. On the other hand, the progression of PCP seems to be faster and higher mortality rates have been reported in non-HIV-infected immunocompromised patient compared to HIV-infected patients [35]. The latter may be due in part to the delay of the initiation of a specific anti-infective therapy $[9,19]$.

\section{Radiological Pattern}

$\mathrm{X}$-ray of the chest may show characteristic findings with a perihilar interstitial infiltrate (Fig. 3; Table 1). In non-HIV-infected immunocompromised patients, the initial chest X-ray may be normal due to the acute onset of symptoms and more rapid progression, but generally the features of the chest X-ray are very similar to those found in HIV-infected patients. Sometimes radiological changes are discreet and the X-ray is often inconclusive or does not show lung pathologies seen on CT scan.

High-resolution CT of the chest should be preferred if available, offering a precise description of the radiological pattern with differentiation to other pulmonary diseases [36]. Ground-glass opacities, often with a central distribution as demonstrated by our patient (Fig. 1), are a common radiological pattern of PCP on CT scans, but the distribution can vary from a mosaic pattern to a 


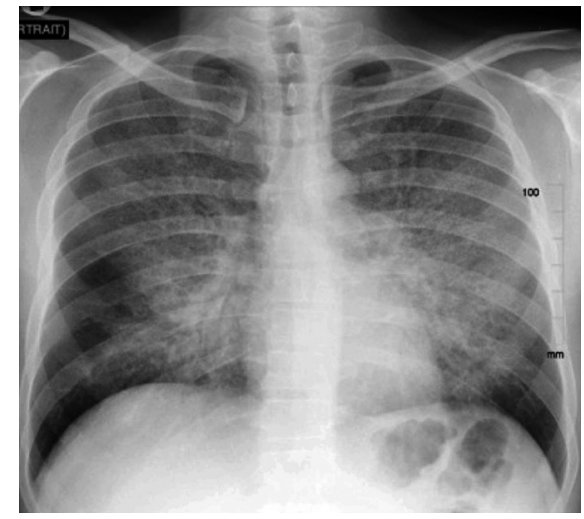

Fig. 3. Chest X-ray showing diffuse bilateral infiltrates due to Pneumocystis jirovecii pneumonia in an HIV-infected patient with AIDS with a CD4+ T lymphocyte count of $15 / \mu \mathrm{L}$.

more diffuse pattern. Upper lobe predominance has been described [36]. Other less common manifestations include nodules, consolidations, or thin-walled cystic lesions, sometimes classified as pneumatocele formation, which are usually associated with the presence of AIDS, whereas non-HIV-infected immunocompromised patients usually present with widespread ground-glass opacities [37-39]. Cystic lesions are often small, bilateral, and multiple, but larger pulmonary cystic lesions with the risk of developing a spontaneous pneumothorax have also been reported (Fig. 4) [40]. The name pneumocystis refers to the microscopic image of the fungus and not to the radiological pattern of the disease. In a prospective study including 30 AIDS patients with respiratory symptoms and an uncertain X-ray, the sensitivity and specificity of high-resolution CT was 100 and $83 \%$, with a positive and negative predictive value of 90.5 and $100 \%$, respectively [36].

\section{Diagnosis of PCP}

In ill patients with clinical suspicion of PCP, empiric treatment should be started immediately. There is no need to delay treatment initiation for diagnostic assessment since cysts persist for several days in respiratory material, even under PCP-specific treatment $[41,42]$.

If possible, bronchoscopy with BAL should be performed, because analysis of BAL fluid provides not only a higher diagnostic yield, but also allows exclusion of alternative diagnoses or coinfections, e.g., tuberculosis (TB), histoplasmosis, cytomegalovirus (CMV), etc. In-

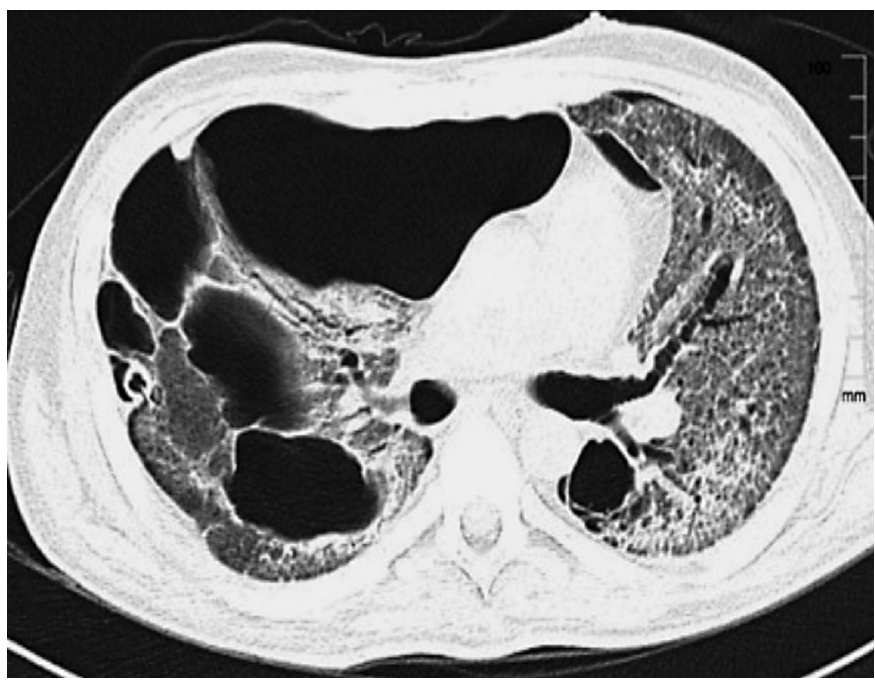

Fig. 4. Axial computed tomography scan of the chest showing large cavities with predominance of the right side and diffuse bilateral ground-glass opacities in an HIV-infected patient with AIDS.

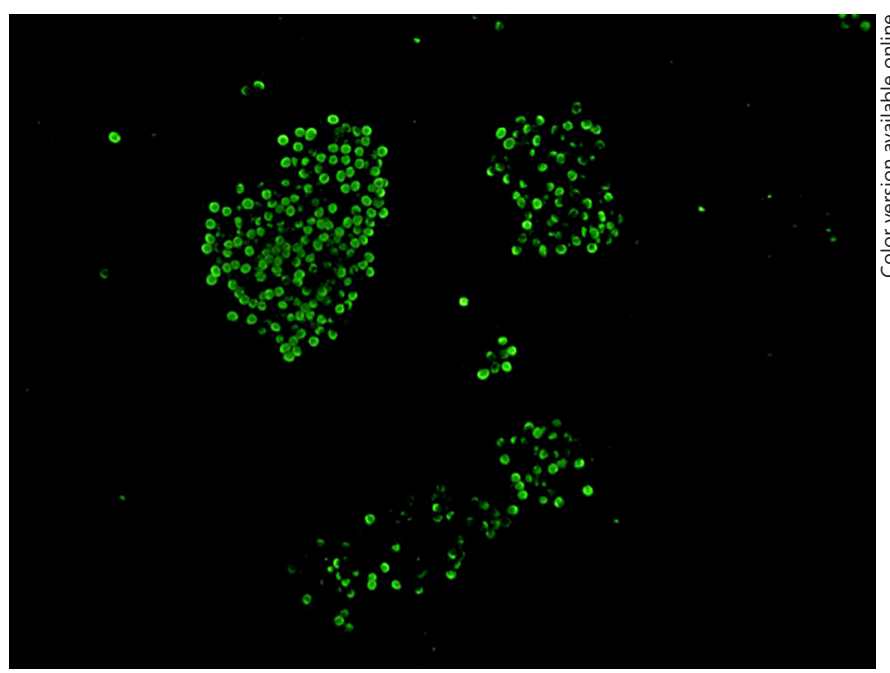

Fig. 5. Microscopic image of an indirect immunofluorescence staining using monoclonal antibodies against the asci/cyst form of Pneumocystis jirovecii (green, $\times 200$ ) in a bronchoalveolar lavage fluid of an HIV-positive patient. Clusters of cysts can be observed.

duced sputum with hypertonic saline is a less invasive alternative, but has a lower sensitivity of 55-90\% [41, 43].

Active pulmonary TB can be excluded either by microscopic smear, by polymerase chain reaction (PCR) (e.g., GenXpert MTB/rifampicin assay; Cepheid Inc., Sunnyvale, CA, USA), and/or by culture from respiratory samples. For most systemic endemic mycoses causing pulmo-
HIV-Infected and Non-HIV-Infected Immunocompromised Patients with PCP 
Table 2. Diagnostic methods for PCP

\begin{tabular}{|c|c|c|c|}
\hline $\begin{array}{l}\text { Microscopy: IF; } \\
\text { conventional } \\
\text { staining }\end{array}$ & $\begin{array}{l}\text { BAL fluid; } \\
\text { induced } \\
\text { sputum }\end{array}$ & $\begin{array}{l}\text { Pros: conventional staining commonly available and } \\
\text { affordable; IF superior to conventional staining } \\
\text { Cons: variable sensitivity of 55-90\% for staining } \\
\text { (depending on material, specific staining, laboratory } \\
\text { experience); less sensitive in HIV-negative } \\
\text { immunocompromised patients (lower number of cysts } \\
\text { and higher number of inflammatory cells in BAL fluid); } \\
\text { consider false-negative test results }\end{array}$ & $\begin{array}{l}\text { BAL should be preferred due to higher } \\
\text { diagnostic yield compared to sputum } \\
\text { examination; different staining methods } \\
\text { with comparable diagnostic performance } \\
\text { (e.g.. calcofluor white, cresyl violet, } \\
\text { Giemsa, Grocott-Gomori methenamine } \\
\text { silver, toluidine blue O, or Papanicolaou } \\
\text { staining) }\end{array}$ \\
\hline PCR & $\begin{array}{l}\text { BAL fluid; } \\
\text { induced } \\
\text { sputum }\end{array}$ & $\begin{array}{l}\text { Pros: sensitivity of PCR > microscopy (conventional } \\
\text { staining and IF); qPCR in BAL fluid [46, 72, 73]: } \\
\text { sensitivity 94-99\%, specificity 89-91\% } \\
\text { Cons: consider false-positive results (e.g., } \\
\text { contamination/colonization); clinical cutoffs not } \\
\text { validated }\end{array}$ & $\begin{array}{l}\text { cutoff: } 8 \text { copies } / 5 \mu \mathrm{L} \text { (area under the ROC } \\
\text { curve } 0.92 \text { ) [46]; genotyping using } \\
\text { multilocus sequence marker for epidemic } \\
\text { investigations }\end{array}$ \\
\hline
\end{tabular}

BAL, bronchoalveolar lavage; IF, immunofluorescence; PCP, Pneumocystis jirovecii pneumonia; PCR, polymerase chain reaction; qPCR, quantitative polymerase chain reaction; ROC, receiver operating characteristic.

nary disease including histoplasmosis, culture or histology from BAL fluid or lung tissue is the method of choice (Salzer et al., Respiration 2018, accepted for publication). To exclude CMV pneumonitis, histology from lung tissue may demonstrate characteristic inclusion bodies, and BAL fluid can be used for CMV culture or for viral load testing using quantitative PCR (qPCR) assays.

$P$. jirovecii does not grow on culture media in vitro. Therefore, PCP diagnosis historically relied on the visualization of cysts or trophic forms from respiratory material (Table 2). Direct or indirect immunofluorescence assay (mainly anticyst antibodies) is the most sensitive microscopic method (Fig. 5) and superior to conventional staining methods (e.g., Grocott-Gomori methenamine silver staining) (Fig. 2). The sensitivity of microscopy is lower in non-HIV-infected compared to HIV-infected patients due to a lower fungal load [42, 44].

PCR is an important additional diagnostic method, especially in non-HIV-infected patients, and may add an additional $7 \%$ diagnostic yield compared to staining methods alone [45]. Real-time qPCR should be preferred as the only PCR method compatible with diagnosis and the Minimum Information for Publication of Quantitative Real-Time PCR Experiments guidelines, but evidence on the validation of clinical cutoffs is limited [45, 46]. This method enables the detection of very low fungal loads, which can be considered as colonization.

A highly sensitive diagnostic method is the serum $(1,3)$ - $\beta$-D-glucan assay characterized by its high negative predictive value that makes a PCP infection unlikely in patients with a negative test result [47]. However, it should not be used as a single diagnostic test for PCP, and positive results should trigger a bronchoscopy with $\mathrm{BAL}$ $[48,49]$. A limitation is that $(1,3)-\beta$-D-glucan testing is frequently not available (at least with time to results of $<24 \mathrm{~h}$ ). However, it is rather easy to establish the test on a coagulation automate and do single-sample testing [50]. Diagnostic guidelines commonly recommend combining different methods, e.g., microscopy (immunofluorescence and conventional staining) and qPCR [42]. When analyzed in parallel with qPCR fungal load, a correlation between both markers is observable, suggesting that circulating $(1,3)-\beta$-D-glucan levels reflect the fungal load in the lungs [51].
Salzer/Schäfer/Hoenigl/Günther/ Hoffmann/Kalsdorf/Alanio/Lange 
Table 3. Treatment regimens for acute PCP

\begin{tabular}{lllll}
\hline Treatment regimens & Route & Dosage & Duration & Commentary \\
\hline First choice & & & \\
\hline TMP/SMX & i.v.; & TMP 15-20 mg and SMX & 21 days & for mild to moderate PCP: p.o. in \\
& p.o. & $\begin{array}{l}75-100 \mathrm{mg} / \mathrm{kg} / \text { day given (i.e., } \\
\text { divided up) every } 6 \text { or } 8 \mathrm{~h}\end{array}$ & $\begin{array}{l}\text { 3 divided doses or TMP/SMX DS - } \\
\text { PCP: start i.v. and switch to p.o. after } \\
\end{array}$ \\
& & & clinical improvement \\
\hline
\end{tabular}

\begin{tabular}{|c|c|c|c|c|}
\hline \multicolumn{5}{|l|}{ Alternative } \\
\hline Atovaquone & p.o. & 750 mg p.o. b.i.d. with food & 21 days & option for mild to moderate disease \\
\hline Pentamidine & i.v. & $\begin{array}{l}4 \mathrm{mg} / \mathrm{kg} \text { i.v. once daily given over } \\
\text { at least } 60 \mathrm{~min}\end{array}$ & 21 days & $\begin{array}{l}\text { option for moderate to severe disease; } \\
\text { may reduce the dose to } 3 \mathrm{mg} / \mathrm{kg} \text { i.v. once } \\
\text { daily in case of toxicity }\end{array}$ \\
\hline $\begin{array}{l}\text { Caspofungin (alone or in } \\
\text { combination with TMP/SMX) }\end{array}$ & i.v. & $\begin{array}{l}\text { caspofungin } 70 \mathrm{mg} \text { on day } 1 / 50 \mathrm{mg} \\
\text { starting on day } 2\end{array}$ & 21 days & second-line (salvage) treatment \\
\hline Prednisone & p.o. & $\begin{array}{l}\text { days 1-5: } 40 \text { mg b.i.d.; days 6-10: } \\
40 \text { mg daily; days 11-21: } 20 \text { mg daily }\end{array}$ & 21 days & $\begin{array}{l}\text { for moderate to severe } \mathrm{PCP} \text { if }(1) \mathrm{PaO}_{2} \\
<70 \mathrm{~mm} \mathrm{Hg} \text { at room air or (2) alveolar- } \\
\text { arterial } \mathrm{O}_{2} \text { gradient } \geq 35 \mathrm{~mm} \mathrm{Hg}\end{array}$ \\
\hline
\end{tabular}

b.i.d., twice daily; DS, double strength; i.v., intravenous; p.o., per os; PCP, Pneumocystis jirovecii pneumonia; SMX, sulfamethoxazole; t.i.d., three times daily; TMP, trimethoprim.

\section{Management of PCP}

\section{Treatment of Acute PCP}

TMP/SMX is the treatment of choice for PCP in adults and children, being as effective as parenteral pentamidine and more effective than other regimens. Treatment is generally administered over 21 days (Table 3) [52]. In patients with mild to moderate disease, oral outpatient therapy with TMP/SMX may be considered. The TMP/SMX dosage needs to be adjusted to renal function (Table 4). TMP/SMX is usually also effective in patients who have PCP despite TMP/SMX prophylaxis [42].

Clinical deterioration may occur during the first 4-8 days of treatment. It is important that this deterioration has been frequently seen in the era before the introduction of highly active ART. Deterioration usually neither indicates immune reconstitution inflammatory syn- drome (IRIS) (very rare) nor treatment failure. It is probably due to an inflammatory response caused by antimicrobial-induced lysis of organisms in the lung (that is why steroids may be helpful). Patients can deteriorate rapidly during treatment, so close monitoring of respiratory rate and arterial oxygenation are essential. Nevertheless, physicians must be aware that clinical worsening rebound phenomena after initial improvements have also been observed in HIV-coinfected patients treated with ART that have been attributed to IRIS [53].

Alternative therapeutic regimens for mild to moderate and moderate to severe disease are depicted in Table 3. Dosages for renal impairment and dosage recommendations for children, as well as the most common adverse events and costs of the therapeutic regimens, are displayed in Table 4. All patients with documented or suspected PCP and moderate to severe disease should receive 
Table 4. Renal adaption, child dosage, side effects, and costs of PCP treatment regimens

\begin{tabular}{|c|c|c|c|c|c|c|c|}
\hline \multirow{2}{*}{$\begin{array}{l}\text { Treatment } \\
\text { regimens }\end{array}$} & \multicolumn{3}{|l|}{ Renal adaption } & \multirow[t]{2}{*}{ Child dosage } & \multirow[t]{2}{*}{ Side effects } & \multirow[t]{2}{*}{ Costs $^{\mathrm{a}}$} & \multirow[t]{2}{*}{ Commentary } \\
\hline & $\begin{array}{l}\text { GFR } \\
10-30 \mathrm{~mL} / \mathrm{min}\end{array}$ & $\begin{array}{l}\text { GFR } \\
<10 \mathrm{~mL} / \mathrm{min}\end{array}$ & dialysis & & & & \\
\hline TMP/SMX & $\begin{array}{l}5 \text { mg/kg (TMP) i.v. } \\
\text { every } 12 \text { h or TMP/ } \\
\text { SMX } 2 \text { DS tablets } \\
\text { p.o. every } 12 \mathrm{~h}\end{array}$ & $\begin{array}{l}5 \mathrm{mg} / \mathrm{kg}(\mathrm{TMP}) \\
\text { i.v. every } 24 \mathrm{~h} \text { or } \\
\text { TMP/SMX DS } \\
\text { tablet p.o. every } \\
12 \mathrm{~h}\end{array}$ & $\begin{array}{l}5 \mathrm{mg} / \mathrm{kg} / \text { day } \\
\text { (TMP) i.v. or } \\
2 \text { TMP/SMX DS } \\
\text { tablets p.o.; dose } \\
\text { after dialysis on } \\
\text { dialysis days }\end{array}$ & $\begin{array}{l}\text { children aged }>2 \text { months: } \\
3.75-5 \mathrm{mg} / \mathrm{kg} / \text { day }(\mathrm{TMP}) \text { and } \\
19-25 \mathrm{mg} / \mathrm{kg} / \text { day }(\mathrm{SMX}) \text { i.v. } \\
\text { every } 6 \mathrm{~h} \text {, given over } 1 \mathrm{~h} \text { for } \\
21 \text { days; for mild to moderate } \\
\text { diseases transition to oral } \\
\text { treatment with same total } \\
\text { daily dose possible; effective } \\
\text { therapeutic serum concentrations: } \\
5-10 \mu \mathrm{g} / \mathrm{mL} \text { TMP }\end{array}$ & $\begin{array}{l}\text { diarrhea, } \\
\text { thrombocytopenia, } \\
\text { hyperkalemia, } \\
\text { gastrointestinal } \\
\text { symptoms, rash, } \\
\text { myalgia, arthralgia, } \\
\text { fever }\end{array}$ & $\begin{array}{l}\text { USD } 0.40 \text { per tablet; } \\
\text { USD } 40 \text { per i.v. dose }\end{array}$ & $\begin{array}{l}\text { in case of dialysis } \\
\text { consider therapeutic } \\
\text { drug monitoring to } \\
\text { optimize therapy } \\
\text { (target TMP } \\
\text { concentrations: } \\
5-8 \mathrm{mg} / \mathrm{mL} \text { ) }\end{array}$ \\
\hline $\begin{array}{l}\text { Dapsone + } \\
\text { TMP }\end{array}$ & $\begin{array}{l}\text { dapsone: probably } \\
\text { no adjustment } \\
\text { needed; TMP: } \\
\text { see above }\end{array}$ & $\begin{array}{l}\text { dapsone: } \\
\text { probably no } \\
\text { adjustment } \\
\text { needed; TMP: } \\
\text { see above }\end{array}$ & $\begin{array}{l}\text { dapsone: probably } \\
\text { no adjustment } \\
\text { needed; TMP: } \\
\text { see above }\end{array}$ & $\begin{array}{l}\text { adolescents: } 100 \mathrm{mg} \text { dapsone } \\
\text { p.o. once daily; in children aged } \\
<13 \text { years: } 2 \mathrm{mg} / \mathrm{kg} \text { dapsone } \\
\text { p.o. once daily; TMP: see above }\end{array}$ & $\begin{array}{l}\text { dapsone: hemolysis, } \\
\text { toxic hepatitis, } \\
\text { hypersensitivity } \\
\text { syndrome }\end{array}$ & $\begin{array}{l}\text { dapsone: USD } 2 \text { per } \\
\text { 25-mg tablet }\end{array}$ & $\begin{array}{l}\text { CAVE: do not use } \\
\text { in those with } \\
\text { glucose-6-phosphate } \\
\text { dehydrogenase } \\
\text { deficiency }\end{array}$ \\
\hline $\begin{array}{l}\text { Clindamycin + } \\
\text { primaquine }\end{array}$ & $\begin{array}{l}\text { clindamycin: } \\
\text { no adjustment; } \\
\text { primaquine: } \\
\text { no data }\end{array}$ & $\begin{array}{l}\text { clindamycin: } \\
\text { no adjustment; } \\
\text { primaquine: } \\
\text { no data }\end{array}$ & $\begin{array}{l}\text { clindamycin: } \\
\text { no adjustment; } \\
\text { primaquine: } \\
\text { no data }\end{array}$ & $\begin{array}{l}\text { infants/children: } 10 \mathrm{mg} / \mathrm{kg} / \text { dose } \\
\text { i.v./p.o. every } 6 \mathrm{~h}(\mathrm{max} .600 \mathrm{mg} \\
\text { i.v., max. } 450 \mathrm{mg} \text { p.o. }) \text { with } \\
\text { primaquine }(0.3 \mathrm{mg} / \mathrm{kg} / \text { day } \\
\text { base); adolescents: } 600 \mathrm{mg} \text { i.v. } \\
\text { every } 6 \mathrm{~h} \text { or } 300 \mathrm{mg} \text { p.o. every } \\
6 \mathrm{~h} \text { or } 450 \mathrm{mg} \text { p.o. every } 8 \mathrm{~h} \text { with } \\
\text { primaquine }(0.3 \mathrm{mg} / \mathrm{kg} / \text { day base })\end{array}$ & $\begin{array}{l}\text { clindamycin: } \\
\text { diarrhea, } \\
\text { gastrointestinal } \\
\text { intolerance; } \\
\text { primaquine: } \\
\text { heartburn, itching, } \\
\text { skin rash, pain or } \\
\text { discomfort in the } \\
\text { chest, upper stomach, } \\
\text { or throat, stomach } \\
\text { cramps }\end{array}$ & $\begin{array}{l}\text { USD } 25 \text { per i.v. } \\
\text { clindamycin/p.o. } \\
\text { primaquine dose }\end{array}$ & limited pediatric data \\
\hline Atovaquone & no data & no data & no data & $\begin{array}{l}\text { adolescents } \geq 13 \text { years: } 750 \mathrm{mg} / \\
\text { dose }(5 \mathrm{~mL}) \text { p.o. twice daily with } \\
\text { food; children }<3 \text { months and } \\
>24 \text { months to } 12 \text { years: } 30-40 \\
\mathrm{mg} / \mathrm{kg} / \text { dose p.o. once a day with } \\
\text { food; children } 2-24 \text { months: } \\
45 \mathrm{mg} / \mathrm{kg} / \text { dose once daily }\end{array}$ & $\begin{array}{l}\text { cough or hoarseness, } \\
\text { difficult or labored } \\
\text { breathing, fever or } \\
\text { chills, lower back or } \\
\text { side pain, painful or } \\
\text { difficult urination, } \\
\text { tightness in the chest }\end{array}$ & $\begin{array}{l}\text { USD } 25 \text { per } 5 \mathrm{~mL} \\
\text { solution }\end{array}$ & \\
\hline Pentamidine & $\begin{array}{l}\text { for GFR } 10-50 \mathrm{~mL} / \\
\mathrm{min}: 3 \mathrm{mg} / \mathrm{kg} \text { i.v. } \\
\text { every } 24 \mathrm{~h}\end{array}$ & $\begin{array}{l}4 \mathrm{mg} / \mathrm{kg} \text { i.v. } \\
\text { every } 48 \mathrm{~h}\end{array}$ & - & $\begin{array}{l}4 \mathrm{mg} / \mathrm{kg} \text { i.v. once daily for } \\
21 \text { days; in case of clinical } \\
\text { improvement switch to oral } \\
\text { atovaquone or TMP/dapsone } \\
\text { after } 7-10 \text { days possible }\end{array}$ & $\begin{array}{l}\text { burning pain, } \\
\text { dryness, or sensation } \\
\text { of lump in throat, } \\
\text { chest pain, coughing, } \\
\text { difficulty in breathing, } \\
\text { difficulty in } \\
\text { swallowing, skin rash, } \\
\text { wheezing, } \\
\text { pancytopenia }\end{array}$ & $\begin{array}{l}\text { USD } 45 \text { per dose } \\
\text {, }\end{array}$ & \\
\hline Caspofungin & no adjustment neede & & & $\begin{array}{l}<3 \text { months: safety and efficacy } \\
\text { not established, limited data } \\
\text { suggest off-label dose of } \\
25 \mathrm{mg} / \mathrm{m}^{2} / \text { dose i.v. once daily; } \\
\geq 3 \mathrm{months} \text { : day } 1 \text { loading dose of } \\
70 \mathrm{mg} / \mathrm{m}^{2} \text { i.v. infused over } 1 \mathrm{~h} \text {, } \\
\text { maintenance } 50 \mathrm{mg} / \mathrm{m}^{2} \text { i.v. } \\
\text { infused over } 1 \mathrm{~h}\end{array}$ & $\begin{array}{l}\text { overall well tolerated; } \\
\text { phlebitis, diarrhea, } \\
\text { and rash may occur }\end{array}$ & USD 300-360 per day & \\
\hline
\end{tabular}

DS, double strength; GFR, glomerular filtration rate; i.v., intravenous; p.o., per os; PCP, Pneumocystis jirovecii pneumonia; SMX, sulfamethoxazole; TMP, trimethoprim. ${ }^{\text {a Costs }}$ depend on each country and are provided for the United States.

adjunctive corticosteroids as early as possible and always within $72 \mathrm{~h}$ after starting specific PCP therapy (Table 3 ). However, this has only been validated in HIV-infected patients and the classification of mild, moderate, and severe disease is not precisely defined. Early predictors of mortality may be useful to asses the risk of death as shown for HIV-infected patients including older age, second or third episode of PCP, low hemoglobin level, low $\mathrm{PaO}_{2}$ breathing room air at admission, pulmonary Kaposi sarcoma, and medical comorbidities [54]. 
Table 5. Primary and secondary prophylaxis in HIV-positive and HIV-negative immunocompromised patients based on available recommendations

\section{HIV-positive patients}

When to start prophylaxis?
CD4 count $<200 / \mu \mathrm{L}$ (or $<14 \%$ of the total lymphocyte count); recurrent thrush or relevant concomitant immunosuppression
HIV-negative immunocompromised patients

allogenic and selected autologous HSCT recipients: from engraftment at least for 6 months and if immunosuppression is ongoing [9]

SOT recipients: for at least 6-12 months post transplantation; consider longer durations (e.g., lung and small bowel transplant, cytomegalovirus disease [26]

hematooncologic patients [58]:

glucocorticoids: dose equivalent $\geq 20 \mathrm{mg}$ of prednisone/day for 1 month or longer alone or in combination with additional immunosuppressive drugs specific recommendations mentioned for alemtuzumab, temozolomide, purine analogs (e.g., fludarabine) acute lymphoblastic leukemia: from induction to end of maintenance

all patients treated successfully for PCP should receive a secondary anti-PCP prophylaxis (same regimens preferred as for primary prophylaxis)

patients with anti-neutrophil cytoplasmic antibody-associated vasculitis receiving cyclophosphamide [32]

consider prophylaxis in immunocompromised patients with a combination of risk factors such as older age and pulmonary comorbidity with higher doses of glucocorticosteroids $(\geq 15-20$ $\mathrm{mg}$ /day) for a longer time period or other immunosuppressive drugs (e.g., TNFa antagonists in inflammatory diseases) or patients with an idiopathic immunodeficiency (e.g., severe combined immunodeficiency or idiopathic CD4 T lymphocytopenia with CD4 cells $<200 / \mu \mathrm{L}$ )

Stopping rule for prophylaxis

CD 4 count $>200$ cells $/ \mu \mathrm{L}$ over 3 months or CD4 count 100-200 cells/ $\mu \mathrm{L}$ and HIV viral load undetectable for 3 months

a stopping rule is generally not defined and the decision should be made on an individual basis (e.g., end of immunosuppressive therapy) [57]

\begin{tabular}{ll}
\hline Treatment of choice & TMP/SMX $400 / 80 \mathrm{mg}$ tablet daily or $800 / 160 \mathrm{mg} 3$ times per week \\
\hline Alternative & There is no widely accepted consensus of a preferred regimen as an alternative to the treatment of choice. In \\
treatments & HIV-positive patients with a positive serology for toxoplasmosis, a pyrimethamine $(+$ folinic acid)-containing \\
& regimen should be preferred. \\
& pentamidine: inhalation, $300 \mathrm{mg}$ in $6 \mathrm{~mL}$ aqua $1-2 \times /$ month \\
& dapsone: $1 \times 2$ tablets à $50 \mathrm{mg}$ (CAVE: dapsone: check for G6PD deficiency) \\
& dapsone $1 \times 50 \mathrm{mg}$ plus pyrimethamine $50-75 \mathrm{mg} 1 \times /$ week plus folinic acid $25-30 \mathrm{mg} 1 \times /$ week p.o. \\
& atovaquone suspension: $1 \times 1,500 \mathrm{mg}$ together with food \\
& atovaquone suspension: $1 \times 1,500 \mathrm{mg}$ together with food + pyrimethamine $50-75 \mathrm{mg} 1 \times /$ week + folinic acid \\
& $25-30 \mathrm{mg} 1 \times /$ week p.o.
\end{tabular}

HSCT, hematopoietic stem cell transplantation; p.o., per os; PCP, Pneumocystis jirovecii pneumonia; SMX, sulfamethoxazole; SOT, solid organ transplantation; TMP, trimethoprim; TNF, tumor necrosis factor.

HIV-Infected and Non-HIV-Infected Immunocompromised Patients with PCP 
ART in Newly Diagnosed HIV-Infected Patients with Acute PCP

In newly diagnosed HIV-infected patients with PCP, ART should be initiated as soon as possible. In a large multicenter trial (ACTG A5164), a total of 282 subjects with an acute opportunistic infection (69\% PCP) were randomized to initiate ART immediately or after treatment of the opportunistic infection [55]. Immediate ART resulted in less AIDS progression and deaths, with no increase in adverse events or loss of virologic response compared to deferred ART. This study provided clear arguments for immediate initiation of ART when PCP is diagnosed.

The risk of a PCP-associated IRIS is low. Given the rapid decay of plasma viremia seen with integrase strand transfer inhibitors (INSTIs), the low prevalence of transmitted INSTI resistance, and the favorable safety profile, INSTI-based regimens seem to be a reasonable option. Antiretroviral drugs with a potential allergenic potential and/or high risk of resistance (non-nucleoside reverse transcriptase inhibitors, abacavir) should be avoided in patients with acute PCP.

\section{Immunosuppressive Drugs during Acute PCP in}

Non-HIV-Infected Immunocompromised Patients

During therapy of acute PCP, it is crucial to reflect all comedications due to many possible drug-drug interactions. As the treatment of choice in patients with acute PCP according to national and international guidelines (see above) is TMP/SMX, methotrexate should be avoided because of potentially increasing adverse drug effects. If possible, immunocompromising treatment should be reduced, paused, or stopped, but this should be an individual approach (depending for instance on the activity of the underlying disease).

Furthermore, it remains unclear whether adjunctive therapy with glucocorticosteroids in non-HIV-infected patients (e.g., in the intensive care unit setting) leads to any benefit for this subgroup [20,56,57]. If patients are already treated with glucocorticosteroids for another reason, there should not be an abrupt discontinuation, though an individual adjustment seems mandatory.

\section{Prophylactic Treatment of Patients at Risk}

Several guidelines give specific recommendations for prophylaxis in HIV-infected patients, and there are recommendations available for hematooncologic and posttransplant patients as well as for patients with anti-neutrophil cytoplasmic antibody-associated vasculitis receiving cyclophosphamide (Table 5) [30, 32, 58]. Otherwise, there is a lack of consensus for otherwise immunocompromised patients [20]. Most evidence exists for regimens containing TMP/SMX [59]. Alternative prophylactic options (e.g., dapsone, atovaquone, or pentamidine) lack evidence for these patients (Table 5) [58]. One of the major challenges is the identification of patients susceptible to $P$. jirovecii infection at an earlier stage of risk to start proper prophylaxis [19]. Monitoring CD4+ T lymphocytes, as in HIV-infected patients, appears to be insufficient to predict the risk of PCP [30].

\section{PCP from a Global Health Perspective with Emphasis on Resource-Limited Settings}

Along with the high burden of HIV infection, particularly in sub-Saharan Africa, PCP infection contributes significantly to HIV-related morbidity and mortality in children and adults. The widespread introduction of PCP prophylaxis as a programmatic intervention as well as the significant rollout of ART has reduced the incidence of PCP infections [60]. Although detailed data are scarce, reports about PCP are available from all continents [61]. In a recent meta-analysis, Wasserman et al. [60] describe a case fatality of $18 \%$ for HIV-infected patients with PCP in sub-Saharan Africa.

The diagnosis of PCP is mostly a presumptive diagnosis in resource-limited settings. Clinical signs and symptoms, particularly dyspnea, fever, dry cough, and hypoxia in absence of an alternative diagnosis in an immunocompromised patient with a CD4+ T lymphocyte count $<200$ cells $/ \mathrm{mL}$ and concurrent radiological changes lead to the initiation of PCP treatment [62]. Very limited availability of diagnostic stains and PCP-specific PCR only infrequently allow a definite diagnosis. Bronchoscopy, bronchial wash, BAL, or transbronchial biopsy, which increase the diagnostic yield over sputum diagnosis, are often not available [60]. A high level of awareness and clinical suspicion is required. A South African autopsy study documented that PCP was not recognized prior to death in $89 \%$ of PCP cases [63]. Due to the high incidence of TB in many resource-limited settings, patients are treated with anti-TB drugs instead. No data can be found on patients requiring invasive or noninvasive ventilation in resource-limited settings, but limited access to such facilities in many settings contributes to higher mortality rates.

Increased LDH levels support the diagnosis and the test is often available. Rising LDH during treatment is associated with poor prognosis [64]. $(1,3)-\beta$-D-glucan is a helpful test to support the diagnosis in absence of a defi-
Salzer/Schäfer/Hoenigl/Günther/ Hoffmann/Kalsdorf/Alanio/Lange 
nite diagnosis in HIV-infected and non-HIV-infected patients, but is not widely available [48]. Very promising reports about the $\mathrm{S}$-adenosylmethionine serum level as a diagnostic marker for PCP could not be independently validated $[65,66]$. A recent approach used real-time qPCR in oral wash to detect PCP tried to establish a cutoff value for infection versus colonization, but this approach needs further studies [67].

$\mathrm{TB}$ is an important differential diagnosis for PCP, but coinfections should also be considered [68]. One autopsy study in South African miners describes cryptococcal pneumonia and bacterial pneumonia as the most frequent coinfections with PCP [63].

Prophylactic treatment with TMP/SMX also reduces the incidence of toxoplasmosis, malaria, and bacterial pneumonias. Particularly in HIV-infected children aged $<5$ years, the World Health Organization recommends a continuous PCP prophylaxis, while in areas with a high incidence of malaria and bacterial pneumonias, this is also an option for adults. In other settings, the prophylaxis can be stopped if the CD4+ T lymphocyte count is $>400$ cells $/ \mu \mathrm{L}$ for more than 3 months or if the viral load is undetectable and the CD4+ T lymphocyte count is 100$200 \mu \mathrm{L}$ for more than 3 months [69].

\section{Conclusions and Discussion}

PCP is presently at a transitional stage with substantial epidemiologic chances. The widespread use of ART has led to an important decline in the PCP incidence in HIVinfected patients worldwide, while the medical progress leads to a growing number of non-HIV-infected immunocompromised patients susceptible for PCP infection. Therefore, physicians should be aware that PCP is an important infectious complication in hematooncologic and posttransplant patients, including SOT or allogenic and autologous HSCT, and in patients under immunosuppressive drugs due to autoimmune diseases. Considering the rapid course of the disease in non-HIV-infected immunocompromised patients, early diagnosis and treatment of acute PCP infection is crucial and can decrease morbidity and mortality. However, we also would like to draw attention to PCP prophylaxis, which sometimes seems to be disregarded in these heterogeneous patient cohorts, although it is effective and helps to combat rising trends.

In case of HIV infection, especially in late presenters who are unaware of their HIV infection and who often present with very low $\mathrm{CD} 4+\mathrm{T}$ lymphocyte counts, there is a high risk of developing PCP. Community-based screening methods, partner services, and simple risk scores can be effective tools to find HIV-unaware individuals $[70,71]$. PCP prophylaxis is of outmost importance and should be initiated in HIV-infected patients with CD4+ T lymphocyte counts $<200 / \mu \mathrm{L}$.

It remains unclear why PCP varies between HIV-infected patients and non-HIV-infected immunocompromised patients, but physicians should be aware of the clinical, diagnostic, and management disparities of acute PCP infection in these heterogeneous patient cohorts.

\section{Acknowledgment}

We thank the patients for giving permission to publish the photographs, and Jessica Hofmeister and Franziska Daduna for the Grocott-Gomori methenamine silver staining of the BAL fluid.

\section{Financial Disclosure and Conflicts of Interest}

The authors declare that no competing interests exist. All authors have submitted the ICMJE Form for Disclosure of Potential Conflict of Interest.

\section{References}

1 Hay JW, Osmond DH, Jacobson MA: Projecting the medical costs of AIDS and ARC in the United States. J Acquir Immune Defic Syndr 1988;1:466-485.

-2 Buchacz K, Lau B, Jing Y, Bosch R, Abraham AG, Gill MJ, Silverberg MJ, Goedert JJ, Sterling TR, Althoff KN, Martin JN, Burkholder G, Gandhi N, Samji H, Patel P, Rachlis A, Thorne JE, Napravnik S, Henry K, Mayor A, Gebo K, Gange SJ, Moore RD, Brooks JT; North American AIDS Cohort Collaboration on Research

HIV-Infected and Non-HIV-Infected Immunocompromised Patients with PCP and Design (NA-ACCORD) of IeDEA: Incidence of AIDS-defining opportunistic infections in a multicohort analysis of HIV-infected persons in the United States and Canada, 2000-2010. J Infect Dis 2016;214:862-872.

3 Buchacz K, Baker RK, Palella FJ Jr, Chmiel JS, Lichtenstein KA, Novak RM, Wood KC, Brooks JT; HOPS Investigators: AIDS-defining opportunistic illnesses in US patients, 1994-2007: a cohort study. AIDS 2010;24: 1549-1559.
4 Opportunistic Infections Project Team of the Collaboration of Observational HIV Epidemiological Research in Europe (COHERE), Mocroft A, Reiss P, Kirk O, Mussini C, Girardi E, Morlat P, Stephan C, De Wit S, Doerholt K, Ghosn J, Bucher HC, Lundgren JD, Chene G, Miro JM, Furrer H: Is it safe to discontinue primary Pneumocystis jirovecii pneumonia prophylaxis in patients with virologically suppressed HIV infection and a CD4 cell count $<200$ cells/microL? Clin Infect Dis 2010;51:611-619. 
5 Kaplan JE, Hanson D, Dworkin MS, Frederick T, Bertolli J, Lindegren ML, Holmberg S, Jones JL: Epidemiology of human immunodeficiency virus-associated opportunistic infections in the United States in the era of highly active antiretroviral therapy. Clin Infect Dis 2000;30(suppl 1):S5-S14.

6 Kelley CF, Checkley W, Mannino DM, Franco-Paredes C, Del Rio C, Holguin F: Trends in hospitalizations for AIDS-associated Pneumocystis jirovecii pneumonia in the United States (1986 to 2005). Chest 2009;136:190-197.

7 Gebo KA, Fleishman JA, Moore RD: Hospitalizations for metabolic conditions, opportunistic infections, and injection drug use among HIV patients: trends between 1996 and 2000 in 12 states. J Acquir Immune Defic Syndr 2005;40:609-616.

-8 Morris A, Lundgren JD, Masur H, Walzer PD, Hanson DL, Frederick T, Huang L, Beard CB, Kaplan JE: Current epidemiology of Pneumocystis pneumonia. Emerg Infect Dis 2004;10: 1713-1720.

-9 Roux A, Canet E, Valade S, Gangneux-Robert F, Hamane S, Lafabrie A, Maubon D, Debourgogne A, Le Gal S, Dalle F, Leterrier M, Toubas D, Pomares C, Bellanger AP, Bonhomme J, Berry A, Durand-Joly I, Magne D, Pons D, Hennequin C, Maury E, Roux P, Azoulay E: Pneumocystis jirovecii pneumonia in patients with or without AIDS, France. Emerg Infect Dis 2014;20:1490-1497.

10 Hoenigl M, Chaillon A, Moore DJ, Morris SR, Mehta SR, Gianella S, Amico KR, Little SJ: Rapid HIV viral load suppression in those initiating antiretroviral therapy at first visit after HIV diagnosis. Sci Rep 2016;6:32947.

$\checkmark 11$ Hoenigl M, Chaillon A, Mehta SR, Smith DM, Graff-Zivin J, Little SJ: Screening for acute HIV infection in community-based settings: cost-effectiveness and impact on transmissions. J Infect 2016;73:476-484.

12 Hoenigl M, Chaillon A, Little SJ: CD4/CD8 cell ratio in acute HIV infection and the impact of early antiretroviral therapy. Clin Infect Dis 2016;63:425-426.

13 Djawe K, Buchacz K, Hsu L, Chen MJ, Selik RM, Rose C, Williams T, Brooks JT, Schwarcz S: Mortality risk after AIDS-defining opportunistic illness among HIV-infected persons - San Francisco, 1981-2012. J Infect Dis 2015;212:1366-1375.

14 Lundberg BE, Davidson AJ, Burman WJ: Epidemiology of Pneumocystis carinii pneumonia in an era of effective prophylaxis: the relative contribution of non-adherence and drug failure. AIDS 2000;14:2559-2566.

15 Mirani G, Williams PL, Chernoff M, Abzug MJ, Levin MJ, Seage GR 3rd, Oleske JM, Purswani MU, Hazra R, Traite S, Zimmer B, Van Dyke RB; IMPAACT P1074 Study Team: Changing trends in complications and mortality rates among US youth and young adults with HIV infection in the era of combination antiretroviral therapy. Clin Infect Dis 2015; 61:1850-1861.
16 Mannheimer SB, Wang L, Wilton L, Van Tieu H, Del Rio C, Buchbinder S, Fields S, Glick S, Connor $\mathrm{MB}$, Cummings V, Eshleman $\mathrm{SH}$, Koblin B, Mayer KH: Infrequent HIV testing and late HIV diagnosis are common among a cohort of black men who have sex with men in 6 US cities. J Acquir Immune Defic Syndr 2014;67:438-445.

17 Lowe DM, Rangaka MX, Gordon F, James CD, Miller RF: Pneumocystis jirovecii pneumonia in tropical and low and middle income countries: a systematic review and meta-regression. PLoS One 2013;8:e69969.

18 McKinnell JA, Cannella AP, Kunz DF, Hook EW 3rd, Moser SA, Miller LG, Baddley JW, Pappas PG: Pneumocystis pneumonia in hospitalized patients: a detailed examination of symptoms, management, and outcomes in human immunodeficiency virus (HIV)-infected and HIV-uninfected persons. Transpl Infect Dis 2012;14:510-518.

19 Bienvenu AL, Traore K, Plekhanova I, Bouchrik M, Bossard C, Picot S: Pneumocystis pneumonia suspected cases in 604 non-HIV and HIV patients. Int J Infect Dis 2016;46:1117.

20 Avino LJ, Naylor SM, Roecker AM: Pneumocystis jirovecii pneumonia in the nonHIV-infected population. Ann Pharmacother 2016;50:673-679.

21 Reid AB, Chen SC, Worth LJ: Pneumocystis jirovecii pneumonia in non-HIV-infected patients: new risks and diagnostic tools. Curr Opin Infect Dis 2011;24:534-544.

22 Matsumura Y, Shindo Y, Iinuma Y, Yamamoto $M$, Shirano $M$, Matsushima A, Nagao $M$, Ito $\mathrm{Y}$, Takakura S, Hasegawa $\mathrm{Y}$, Ichiyama S: Clinical characteristics of Pneumocystis pneumonia in non-HIV patients and prognostic factors including microbiological genotypes. BMC Infect Dis 2011;11:76.

-23 Li MC, Lee NY, Lee CC, Lee HC, Chang CM, Ko WC: Pneumocystis jirovecii pneumonia in immunocompromised patients: delayed diagnosis and poor outcomes in non-HIV-infected individuals. J Microbiol Immunol Infect 2014;47:42-47.

24 Yu Q, Jia P, Su L, Zhao H, Que C: Outcomes and prognostic factors of non-HIV patients with Pneumocystis jirovecii pneumonia and pulmonary CMV co-infection: a retrospective cohort study. BMC Infect Dis 2017;17:392.

25 Radisic M, Lattes R, Chapman JF, del Carmen Rial M, Guardia O, Seu F, Gutierrez P, Goldberg J, Casadei DH: Risk factors for Pneumocystis carinii pneumonia in kidney transplant recipients: a case-control study. Transpl Infect Dis 2003;5:84-93.

26 Martin SI, Fishman JA; AST Infectious Diseases Community of Practice: Pneumocystis pneumonia in solid organ transplantation. Am J Transplant 2013;13(suppl 4):272-279.

27 Roblot F: Management of Pneumocystis pneumonia in patients with inflammatory disorders. Expert Rev Anti Infect Ther 2005; 3:435-444.
28 Ahn IE, Jerussi T, Farooqui M, Tian X, Wiestner A, Gea-Banacloche J: Atypical Pneumocystis jirovecii pneumonia in previously untreated patients with CLL on single-agent ibrutinib. Blood 2016;128:1940-1943.

29 Cordonnier C, Cesaro S, Maschmeyer G, Einsele H, Donnelly JP, Alanio A, Hauser PM, Lagrou K, Melchers WJ, Helweg-Larsen J, Matos O, Bretagne S, Maertens J; Fifth European Conference on Infections in Leukemia (ECIL-5), a joint venture of the European Group for Blood and Marrow Transplantation (EBMT), the European Organization for Research and Treatment of Cancer (EORTC), the Immunocompromised Host Society (ICHS) and the European LeukemiaNet (ELN): Pneumocystis jirovecii pneumonia: still a concern in patients with haematological malignancies and stem cell transplant recipients. J Antimicrob Chemother 2016;71:23792385.

30 Calero-Bernal ML, Martin-Garrido I, Donazar-Ezcurra M, Limper AH, Carmona EM: Intermittent courses of corticosteroids also present a risk for Pneumocystis pneumonia in non-HIV patients. Can Respir J 2016;2016: 2464791.

31 Harigai M, Koike R, Miyasaka N; Pneumocystis Pneumonia under Anti-Tumor Necrosis Factor Therapy (PAT) Study Group: Pneumocystis pneumonia associated with infliximab in Japan. N Engl J Med 2007;357:18741876.

32 Yates M, Watts RA, Bajema IM, Cid MC, Crestani B, Hauser T, Hellmich B, Holle JU, Laudien M, Little MA, Luqmani RA, Mahr A, Merkel PA, Mills J, Mooney J, Segelmark M, Tesar V, Westman K, Vaglio A, Yalcindag N, Jayne DR, Mukhtyar C: EULAR/ERA-EDTA recommendations for the management of ANCA-associated vasculitis. Ann Rheum Dis 2016;75:1583-1594.

33 Martin-Garrido I, Carmona EM, Specks U, Limper AH: Pneumocystis pneumonia in patients treated with rituximab. Chest 2013;144: 258-265.

34 Grubbs JA, Baddley JW: Pneumocystis jirovecii pneumonia in patients receiving tumornecrosis-factor-inhibitor therapy: implications for chemoprophylaxis. Curr Rheumatol Rep 2014;16:445.

35 Kovacs JA, Hiemenz JW, Macher AM, Stover D, Murray HW, Shelhamer J, Lane HC, Urmacher C, Honig C, Longo DL, et al: Pneumocystis carinii pneumonia: a comparison between patients with the acquired immunodeficiency syndrome and patients with other immunodeficiencies. Ann Intern Med 1984; 100:663-671.

36 Hidalgo A, Falco V, Mauleon S, Andreu J, Crespo M, Ribera E, Pahissa A, Caceres J: Accuracy of high-resolution CT in distinguishing between Pneumocystis carinii pneumonia and non-Pneumocystis carinii pneumonia in AIDS patients. Eur Radiol 2003;13:11791184. 
37 Hardak E, Brook O, Yigla M: Radiological features of Pneumocystis jirovecii pneumonia in immunocompromised patients with and without AIDS. Lung 2010;188:159-163.

- 38 Tokuda H, Sakai F, Yamada H, Johkoh T, Imamura A, Dohi M, Hirakata M, Yamada T, Kamatani N, Kikuchi Y, Sugii S, Takeuchi T, Tateda K, Goto H: Clinical and radiological features of Pneumocystis pneumonia in patients with rheumatoid arthritis, in comparison with methotrexate pneumonitis and Pneumocystis pneumonia in acquired immunodeficiency syndrome: a multicenter study. Intern Med 2008;47:915-923.

-39 Tasaka S, Tokuda H, Sakai F, Fujii T, Tateda K, Johkoh T, Ohmagari N, Ohta H, Araoka H, Kikuchi Y, Yasui M, Inuzuka K, Goto $\mathrm{H}$ : Comparison of clinical and radiological features of Pneumocystis pneumonia between malignancy cases and acquired immunodeficiency syndrome cases: a multicenter study. Intern Med 2010;49:273-281.

-40 Salzer HJF, Heyckendorf J, Kalsdorf B, Herzmann C, Hoffmann C, Lange C: Chronic cough and severe weight loss in a 55-year-old previously healthy man. Clin Infect Dis 2017; 65:349-351.

41 Limper AH, Offord KP, Smith TF, Martin WJ 2nd: Pneumocystis carinii pneumonia. Differences in lung parasite number and inflammation in patients with and without AIDS. Am Rev Respir Dis 1989;140:1204-1209.

- 42 Alanio A, Hauser PM, Lagrou K, Melchers WJ, Helweg-Larsen J, Matos O, Cesaro S, Maschmeyer G, Einsele H, Donnelly JP, Cordonnier C, Maertens J, Bretagne S; 5th European Conference on Infections in Leukemia (ECIL-5), a joint venture of the European Group for Blood and Marrow Transplantation (EBMT), the European Organization for Research and Treatment of Cancer (EORTC), the Immunocompromised Host Society (ICHS) and the European LeukemiaNet (ELN): ECIL guidelines for the diagnosis of Pneumocystis jirovecii pneumonia in patients with haematological malignancies and stem cell transplant recipients. J Antimicrob Chemother 2016;71:2386-2396.

43 Pagano L, Fianchi L, Mele L, Girmenia C, Offidani M, Ricci P, Mitra ME, Picardi M, Caramatti C, Piccaluga P, Nosari A, Buelli M, Allione B, Cortelezzi A, Fabbiano F, Milone G, Invernizzi R, Martino B, Masini L, Todeschini G, Cappucci MA, Russo D, Corvatta L, Martino P, Del Favero A: Pneumocystis carinii pneumonia in patients with malignant haematological diseases: 10 years' experience of infection in GIMEMA centres. Br J Haematol 2002;117:379-386.

-44 Alanio A, Desoubeaux G, Sarfati C, Hamane S, Bergeron A, Azoulay E, Molina JM, Derouin F, Menotti J: Real-time PCR assaybased strategy for differentiation between active Pneumocystis jirovecii pneumonia and colonization in immunocompromised patients. Clin Microbiol Infect 2011;17:15311537.
45 Wilson JW, Limper AH, Grys TE, Karre T, Wengenack NL, Binnicker MJ: Pneumocystis jirovecii testing by real-time polymerase chain reaction and direct examination among immunocompetent and immunosuppressed patient groups and correlation to disease specificity. Diagn Microbiol Infect Dis 2011;69: 145-152.

46 Moodley B, Tempia S, Frean JA: Comparison of quantitative real-time PCR and direct immunofluorescence for the detection of Pneumocystis jirovecii. PLoS One 2017;12: e0180589.

-47 Karageorgopoulos DE, Qu JM, Korbila IP, Zhu YG, Vasileiou VA, Falagas ME: Accuracy of beta-D-glucan for the diagnosis of Pneumocystis jirovecii pneumonia: a meta-analysis. Clin Microbiol Infect 2013;19:39-49.

-48 Sax PE, Komarow L, Finkelman MA, Grant PM, Andersen J, Scully E, Powderly WG, Zolopa AR; AIDS Clinical Trials Group Study A5164 Team: Blood (1->3)-beta-D-glucan as a diagnostic test for HIV-related Pneumocystis jirovecii pneumonia. Clin Infect Dis 2011; 53:197-202.

49 Onishi A, Sugiyama D, Kogata Y, Saegusa J, Sugimoto T, Kawano S, Morinobu A, Nishimura K, Kumagai S: Diagnostic accuracy of serum 1,3-beta-D-glucan for Pneumocystis jirovecii pneumonia, invasive candidiasis, and invasive aspergillosis: systematic review and meta-analysis. J Clin Microbiol 2012;50:7-15.

50 Prüller F, Wagner J, Raggam RB, Hoenigl M, Kessler HH, Truschnig-Wilders M, Krause R: Automation of serum (1->3)-beta-D-glucan testing allows reliable and rapid discrimination of patients with and without candidemia. Med Mycol 2014;52:455-461.

51 Damiani C, Le Gal S, Da Costa C, Virmaux M, Nevez G, Totet A: Combined quantification of pulmonary Pneumocystis jirovecii DNA and serum (1->3)-beta-D-glucan for differential diagnosis of Pneumocystis pneumonia and Pneumocystis colonization. J Clin Microbiol 2013;51:3380-3388.

52 Safrin S, Finkelstein DM, Feinberg J, Frame P, Simpson G, Wu A, Cheung T, Soeiro R, Hojczyk P, Black JR: Comparison of three regimens for treatment of mild to moderate Pneumocystis carinii pneumonia in patients with AIDS. A double-blind, randomized, trial of oral trimethoprim-sulfamethoxazole, dapsone-trimethoprim, and clindamycin-primaquine. ACTG 108 Study Group. Ann Intern Med 1996;124:792-802.

53 Wislez M, Bergot E, Antoine M, Parrot A, Carette MF, Mayaud C, Cadranel J: Acute respiratory failure following HAART introduction in patients treated for Pneumocystis carinii pneumonia. Am J Respir Crit Care Med 2001;164:847-851.

54 Walzer PD, Evans HE, Copas AJ, Edwards SG, Grant AD, Miller RF: Early predictors of mortality from Pneumocystis jirovecii pneumonia in HIV-infected patients: 1985-2006. Clin Infect Dis 2008;46:625-633.
55 Zolopa A, Andersen J, Powderly W, Sanchez A, Sanne I, Suckow C, Hogg E, Komarow L: Early antiretroviral therapy reduces AIDS progression/death in individuals with acute opportunistic infections: a multicenter randomized strategy trial. PLoS One 2009;4: e5575.

56 Moon SM, Kim T, Sung H, Kim MN, Kim SH, Choi SH, Jeong JY, Woo JH, Kim YS, Lee SO: Outcomes of moderate-to-severe Pneumocystis pneumonia treated with adjunctive steroid in non-HIV-infected patients. Antimicrob Agents Chemother 2011;55:4613-4618.

57 Maschmeyer G, Helweg-Larsen J, Pagano L, Robin C, Cordonnier C, Schellongowski P; 6th European Conference on Infections in Leukemia (ECIL-6), a joint venture of the European Group for Blood and Marrow Transplantation (EBMT), the European Organization for Research and Treatment of Cancer (EORTC), the International Immunocompromised Host Society (ICHS) and the European LeukemiaNet (ELN): ECIL guidelines for treatment of Pneumocystis jirovecii pneumonia in non-HIV-infected haematology patients. J Antimicrob Chemother 2016;71: 2405-2413.

58 Maertens J, Cesaro S, Maschmeyer G, Einsele H, Donnelly JP, Alanio A, Hauser PM, Lagrou K, Melchers WJ, Helweg-Larsen J, Matos O, Bretagne S, Cordonnier C; 5th European Conference on Infections in Leukaemia (ECIL-5), a joint venture of the European Group for Blood and Marrow Transplantation (EBMT), the European Organization for Research and Treatment of Cancer (EORTC), the Immunocompromised Host Society (ICHS) and the European LeukemiaNet (ELN): ECIL guidelines for preventing Pneumocystis jirovecii pneumonia in patients with haematological malignancies and stem cell transplant recipients. J Antimicrob Chemother 2016;71:2397-2404.

59 Stern A, Green H, Paul M, Vidal L, Leibovici L: Prophylaxis for Pneumocystis pneumonia (PCP) in non-HIV immunocompromised patients. Cochrane Database Syst Rev 2014;10: CD005590.

60 Wasserman S, Engel ME, Griesel R, Mendelson M: Burden of Pneumocystis pneumonia in HIV-infected adults in sub-Saharan Africa: a systematic review and meta-analysis. BMC Infect Dis 2016;16:482

61 de Armas Rodriguez Y, Wissmann G, Muller AL, Pederiva MA, Brum MC, Brackmann RL, Capo de Paz V, Calderon EJ: Pneumocystis jirovecii pneumonia in developing countries. Parasite 2011;18:219-228.

62 Stansell JD, Osmond DH, Charlebois E, LaVange L, Wallace JM, Alexander BV, Glassroth J, Kvale PA, Rosen MJ, Reichman LB, Turner JR, Hopewell PC: Predictors of Pneumocystis carinii pneumonia in HIV-infected persons. Pulmonary Complications of HIV Infection Study Group. Am J Respir Crit Care Med 1997;155:60-66.
HIV-Infected and Non-HIV-Infected Immunocompromised Patients with PCP 
63 Wong ML, Back P, Candy G, Nelson G, Murray J: Pneumocystis jirovecii pneumonia in African miners at autopsy. Int J Tuberc Lung Dis 2006; 10:756-760.

64 Butt AA, Michaels S, Kissinger P: The association of serum lactate dehydrogenase level with selected opportunistic infections and HIV progression. Int J Infect Dis 2002;6:178181.

65 Skelly MJ, Holzman RS, Merali S: S-adenosylmethionine levels in the diagnosis of Pneumocystis carinii pneumonia in patients with HIV infection. Clin Infect Dis 2008;46:467-471.

-66 de Boer MG, Gelinck LB, van Zelst BD, van de Sande WW, Willems LN, van Dissel JT, de Jonge R, Kroon FP: Beta-D-glucan and S-adenosylmethionine serum levels for the diagnosis of Pneumocystis pneumonia in HIV-negative patients: a prospective study. J Infect 2011;62:93-100.
67 Hviid CJ, Lund M, Sørensen A, EllermannEriksen S, Jespersen B, Dam MY, Dahlerup JF, Benfield T, Jespersen S, Østergaard LJ, Laursen AL; Bissau HIV Cohort Study Group: Detection of Pneumocystis jirovecii in oral wash from immunosuppressed patients as a diagnostic tool. PLoS One 2017;12:e0174012.

68 Yamao S, Jint T, Nishimura N, Fujiwara M, Suzuki K, Chohnabayashi N: Coinfection with Pneumocystis jirovecii and Mycobacterium tuberculosis in a patient with AIDS: a first report in Japan (in Japanese). Nihon Kokyuki Gakkai Zasshi 2011;49:192-196.

69 World Health Organization: Consolidated guidelines on: The use of antiretroviral drugs for treating and preventing HIV infection; recommendations for a public health approach. Second edition 2016.
70 Green N, Hoenigl M, Chaillon A, Anderson CM, Kosakovsky Pond SL, Smith DM, Little SJ: Partner services in adults with acute and early HIV infection. AIDS 2017;31:287-293.

71 Lin TC, Gianella S, Tenenbaum T, Little SJ, Hoenigl M: A simple symptom score for acute HIV infection in a San Diego community based screening program. Clin Infect Dis 2017, Epub ahead of print.

72 Fan LC, Lu HW, Cheng KB, Li HP, Xu JF: Evaluation of PCR in bronchoalveolar lavage fluid for diagnosis of Pneumocystis jirovecii pneumonia: a bivariate meta-analysis and systematic review. PLoS One 2013;8:e73099.

73 Lu Y, Ling G, Qiang C, Ming Q, Wu C, Wang $\mathrm{K}$, Ying Z: PCR diagnosis of Pneumocystis pneumonia: a bivariate meta-analysis. J Clin Microbiol 2011;49:4361-4363. 